\title{
The World Health Organization in Crisis_-Lessons to be Learned Beyond the Ebola Outbreak
}

\author{
Nadja Meisterhans \\ Medico International, Frankfurt (Germany); Karlshochschule International \\ University, Karlsruhe (Germany); Johannes Kepler Universität, Linz (Austria) \\ nmeisterhans@karlshochschule.de
}

\begin{abstract}
Blaming the World Health Organization (wHo) for its failures in the Ebola crisis was a common reaction of the media. However, exclusively denouncing the wHo for the spread of Ebola falls short as it does not recognize the structural deficits of those recent governance procedures financing global health that lead to a chronic underfunding of the wHo. Against this background, the article reflects perspectives of a democratic reform of global health funding. It concludes that only the wHo can provide a leadership on global health matters, but to do so it depends on states willing to rebuild the wHo's capacities to act. To address the global health crisis properly, the revitalization of WHO's constitutional mandate is critically necessary. The discussion is based on normative legal theory, which argues that processes of globalization have transformed international law into a global rule of law, placing specific duties on states and international institutions.
\end{abstract}

\section{Keywords}

wHO reform - Human right to health - Global rule of law - Global governance for health -Legal theory

* The research for this article was supported by Medico International. 
Blaming the wHo for its failures in the Ebola crisis is a common reaction, frequently articulated in the public discourse. ${ }^{1}$ The wHo's response is criticized as too slow and inefficient. However, to exclusively denounce the wHo for the spread of Ebola cannot be completely justified as it does not recognize the structural deficits of those recent governance procedures financing global health that lead to a chronic underfunding of the wHo.

It is beyond doubt that weak institutions cannot be made stronger only by increasing their funds. What is needed is to rethink instruments and procedures for financing health and this implies a governance structure that goes beyond short-term interventions and crises management, ensuring a sustainable funding of global health. If there is one crucial lesson to be learned from the current Ebola outbreak in western Africa, it is that in order to expand weak health systems' capacities and to tackle the global deficit of the workforce a global response is required, and an approach which transcends national boundaries and self-interest.

On 25 January 2015, the wHo held a special session on the Ebola emergency situation. There was a consensus over the fact that well-functioning health systems are an essential global health issue. Such debates can be seen as indication that a rethinking process has started. However, the crucial question is whether this process opens a window for a new paradigm for funding global health. ${ }^{2}$

The paper has a starting point in this debate and argues that Global Governance for funding health in general needs to be reframed on the base of a human rights approach. The problem is that the given global health financing mechanism tends to favor short-term global interests at the expense of long-term capacity building within national and community-based health systems. These shortcomings not only document a precarious commitment of

1 Just to name a few headlines in European, American, Asian and African newspapers: "Ebola crisis: WHO accused of 'failure' in early response", in ввС (Great Britain), 17 October 2014, http://www.bbc.com/news/world-africa-29668603 (accessed 14 May 2015); "Out of control. How the world's health organizations failed to stop the Ebola disaster" in: Washington Post (USA), 4 October 2014, http://www.washingtonpost.com/sf/national/2014/10/04/how-ebolasped-out-of-control/ (accessed 14 May 2015); "WHO's Ebola response 'a failure'" in: The Straight Times (Singapore), 8 July 2015, http://www.straitstimes.com/world/whos-ebolaresponse-a-failure (accessed 9 July 2015); "wHO reform needed' after Ebola failure" in: New Vision (Uganda), 8 May 2015, http://www.newvision.co.ug/news/668065--who-reformneeded-after-ebola-failure.html (accessed 9 July 2015).

2 Ilona Kickbusch and K. Sinrath Reddy, "Global health governance-the next political revolution." Public Health 129 (2015), p. 838-42. 
the international community to recognize the critical importance of strengthening health systems as a whole, but also its unwillingness to support the WHO as global authority for achieving the highest level of health for everyone.

Against this background, the thesis will be formulated in such a way that only the wHо can provide a leadership on global health matters; but to do so it depends on states taking action to rebuild the WHo's capacities to act. From a normative anchor the situation is clear: The Universal Declaration of Human Rights (UDHR) commits states to realize human rights and if a single state fails to do so the international community "has a responsibility to step in." ${ }^{3}$ Regarded from this perspective, the wH $\mathrm{O}$ can be seen as an organization in which this responsibility has become institutionalized on a global scale. Therefore, states should have an intrinsic interest in supporting the wHo.

The article deals with two core issues. First, failures of the international community in the context of financing global health will be analyzed. Second, it will be outlined that the UDHR has inspired the constitution of the WHO and furthermore, that the wHO is already part of a United Nations-based system of a global rule of law that places specific duties on states.

Against this background the paper makes to central recommendations: The first is that the funding structure should be reformed. The second recommendation is that this reform should be based on democratic principles and procedures.

I will conclude by saying that in order to address the global health crisis properly, the recovery of the wHO and a revitalization of its constitutional mandate is, for normative but also for political reasons, critically necessary.

\section{2 The Role and Structure of the wно}

At first, it should be recognized that the wHO is an international health organization of tremendous importance. It coordinates international health issues, it advises the governments of the member states on developing their public health and social services, it gives technical instructions, it supports governments in eradicating world diseases, it formulates standards for medical education and scientific research, and last but not least, it is the only United

3 Rachel Hammonds and Gorik Ooms, "Global constitutionalism, responsibility to protect, and extra-territorial obligations to realize the right to health: time to overcome the double standard (once again)", International Journal for Equity in Health 13 (2014). For the general obligation in the context of international law, see: International Commission on Intervention and State Sovereignty (ICISs), The Responsibility to Protect, The Report of the International Commission on Intervention and State Sovereignty, Ottawa, 2001, www.iciss.ca/menu-en.asp. 
Nations (UN) body that has the mandate to health-related treaties. ${ }^{4}$ That is to say that the wHo "is the only organization in global health that is mandated by its constitution to "act as the directing and co-ordinating authority on international health work." 5

The WHO is a specialized agency of the UN that comprises 194 state members who meet once a year at the World Health Assembly. The Assembly is the highest decision-making body and it is here that agreements on the program, policies and the budget are made. These agreements are not binding-nevertheless, this body has an important role as it gives public space for deliberation and controversial reflections on relevant health issues. Additionally, there is an Executive Board composed of 34 members who are elected for three-year terms. The wHo's formal structure is fairly democratically organized. It is based on state-cooperation, giving each member state in the Word Heath Assembly one vote, even if a state is not formally recognized in the UN system. Therefore, at least in the classical perspective of internal relations - that is the state-centered understanding of the international community and international law-it fulfills a modest idea of inclusive representation. ${ }^{6}$ It should be highlighted that the w HO "is the only organization in global health that is mandated by its constitution to act as the directing and coordinating authority on international health work."7 Moreover, the constitution is based on the idea that health is a fundamental right of human beings and that there is an international obligation to implement this right (health for all). The constitution also documents an intersectional understanding of

4 See for example, The Framework Convention on Tobacco Control, http://www.who.int/fctc/ text_download/en/ (accessed 13 February 2015).

5 With reference to the constitution: Ilona Kickbusch et al., 'Addressing Global Health Governance Challenges through a New Mechanism: The Proposal for a Committee C of the World Health Assembly'. The Journal of Law, Medicine \& Ethics 38 (2010), p. 553.

6 Christian Reus-Smit and Duncan Snidal, The Oxford Handbook of International Relations, Oxford: Oxford University Press, 2008. Naturally, one has to acknowledge that in the last decades there has been an intense debate on the fundamental democratic deficit of Global Governance and on the crisis of legitimacy and representation. Against this background, I will recommend a further democratization of the wHO at the end of my article. See for example: Jürgen Habermas: The Constitutionalization of International Law and the Legitimation Problems of a Constitution for World Society; Hauke Brunkhorst. "Constitutionalism and Democracy in the World Society", in Petra Dobner and Martin Loughlin (ed): The Twilight of Constitutionalism, Oxford: OUP, 2010, p. 179-200.

7 With reference to the constitution of the who: Ilona Kickbusch et al. 'Addressing Global Health Governance Challenges through a New Mechanism: The Proposal for a Committee C of the World Health Assembly'. The Journal of Law, Medicine \& Ethics (2010) 38, p. 553. 
health issues meaning that there is awareness that the improvement of the global health situation depends on a complex co-ordination of different policy fields such as ecology and economy. In other words the constitution not only addresses state actors but also other relevant players in the global health context. $^{8}$

The wно is a large and highly decentralized organization, with more than 7,000 employees on its staff and more than 150 offices worldwide-including the headquarters and six regional offices. ${ }^{9}$

The wHo has its headquarters in Geneva but also hosts relatively independent regional offices for Europe, Africa, the Americas, Western Pacific, South Asia, and the Eastern Mediterranean Region. The regional offices' duties are to coordinate and implement international health issues on a regional level and in particular to monitor and evaluate the health situation. At least in theory, due to this decentralized governance structure, the wHo offers a strong voice to the differing needs of the regions enabling a compromise between the requirements and demands of northern and southern countries. ${ }^{10}$

The wHO's agenda is complex. It deals with communicable diseases, in particular human immunodeficiency virus (HIV)/acquired immunodeficiency syndrome (AIDS), malaria, tuberculosis, Ebola; the alleviation of the effects of non-communicable diseases; development, sexual and reproductive health, aging; nutrition, food security and healthy eating; occupational health; substance abuse; and it is driving the development of reporting, publications, and networking. Moreover, wHO is responsible for the World Health Report, a leading international publication on health and a relevant instrument for informing on health action. ${ }^{11}$

The wHO is a norm-setting institution. In its constitution it commits the member states to guarantee their citizens "the highest attainable standard of health". Thus, this demand is justified on the normative base of the "fundamental rights of every human being". Additionally, in 1978 at the wHo conference in Alma Ata the concept of "Primary Health Care" was developed, outlining a holistic approach to health care, based on social and structural determinants

$8 \quad$ Ibid.

9 World Health Organization, "African Programme for Onchocerciasis Control. About us. Governance, structure and partners", http://www.who.int/apoc/about/structure/en/ (accessed 13 February 2015).

10 Ibid.

11 World Health Organization, "Health Topics". http://www.who.int/topics/en/ (accessed 13 February 2015). 
of health. ${ }^{12}$ Furthermore, in 2005 the World Health Assembly ratified a resolution demanding that every person "should be able to access health services and not be subject to financial hardship" (Resolution No. 58.33). ${ }^{13}$ Due to these normative settings, the wHO not only has a responsibility as a global authority for health, but also relishes legitimacy as an international institution by charting a valiant vision of health-for-all. It has a unique role to play in addressing the health needs of people around the globe and vulnerable populations in particular. Many developing countries are "heavily depending on the wHo for technical and scientific advice to fulfill their obligations on the right to health".14

Despite previous successes, such as the active support of the global polio eradication in the past, the WHO has lost its capacity to act. The wHo's reactions to the Ebola crisis were dramatic evidence of its deprived operational competences. ${ }^{15}$

But why is the wHO in crisis, and how did this effect the Ebola epidemic? First, internal problems of the WHO should be mentioned, such as a bloated bureaucracy and, to some extent, poorly organized decentralized structures, impairing the work of the regional offices. Although the wHo has been built on a cooperative scheme, this structure has caused various blockades due to malfunctioning internal communication and motives of self-interest of its member states.

Here, the recent Ebola crisis is a good illustration. The wHo Regional Office for Africa in Congo-Brazzaville, for example, was equipped with staff selected in accordance with political discretion and convenience of the respective governments and not according to competence. The consequence of this deficient recruitment strategy was a staff lacking motivation and fundamentally

12 The social determinants of health are the conditions in which people are born, grow, live, work and based on their age. These circumstances are shaped by the distribution of money, power and resources at global, national and local levels. See: http://www.who.int/ social_determinants/en/.

13 World Health Organization, The World Health Report-Health Systems Financing: The Path to Universal Health Coverage, Geneva: wHo Press, 2010, p. 10.

14 K. M. Gopakumar, Third World Network, Oral and Postal Interview with author, 6 August 2014.

15 Lawrence O. Gostin and Eric A. Friedman, "A retrospective and prospective analysis of the West African Ebola virus disease epidemic: robust national health systems at the foundation and an empowered wHO at the apex", The Lancet 385 (2015), p. 1902-09. 
unwilling to co-ordinate actions between the regional offices and the wHO headquarters in Geneva. This structure created a situation where early reports of health workers on the outbreak of Ebola were not taken seriously. Therefore, the central office in Geneva was informed relatively late on the scale of the epidemic. This kind of malfunctioning is symptomatic. Already in the past, regional offices where not coordinated properly due to clientelistic motives of its member states, fending off instructions from the headquarters. ${ }^{16}$

\section{The wH O - on the Brink of Financial Collapse}

However, the major cause for the limited capacities of the wHO is its financing structure. Like many UN agencies, the WHO is chronically underfinanced and therefore heavily dependent on the financial support from donors. One of the biggest difficulties the WHO is struggling with is that its normative mandate and functional role have become blurred. This is due to the lack of logistical and financial capacity to manage what morphed into one of the largest public health crises. Not at least because of these limited capacities to act, the WHO has been in an ongoing reform process since 2011. However, this process is only progressing slowly due to various blockades caused by a general lack of commitment of its members to accomplish health as a common good.

One of the biggest problems the WHO is facing is the 'de facto' control of a handful of financially powerful donors setting the global health agenda setting false priorities within the context of strategic directions. ${ }^{17}$

The World Health Organization is funded by contributions from member states and voluntary contributions. States are still the main donors. Apart from United States of America (USA) and Japan, Germany is the third largest donor. However, only $20 \%$ of the annual budget comes from regular membership fees, whereas grants and earmarked funds account for $80 \%$. The latter are provided by individual countries, large private foundations, companies or financially strong NGOS. The problem with this kind of funding is that it is bound only to selected projects and programs.

As a consequence, the wHO is losing control over the agenda setting and implementation and, even worse, a problematic competition between the

16 Tine Hanrieder, "The Path Dependent Design of International Organizations: Federalism in the World Health Organization", European Journal of International Relations 21 (2015), p. 215-239.

17 Remco Van de Pas and Sara van Belle, "Ebola, the epidemic that should never have happened", Global Affairs 1 (2015), p. 95-100. 
various WHO-related health programs is taking place as they are each depending on the goodwill of the donors. Furthermore, it has to be noted that the donor interests are not automatically in line with the needs of the majority of the people, the poor and the rural segments especially, coming from low and middle income countries. Frequently, a health agenda dictated by big donors disrespects any alternative path to Global Governance for health by the people, not least because its funding is tied to specific projects and thus, resource allocation is distorted. ${ }^{18}$ What follows is a permanent conflict between public and private (commercial) interests as funding practices are often connected to profit-oriented investment policies, in which rich countries of the North and Brazil, Russia, India, and China (BRIC) countries act as donors and thus reduce recipient-countries to the role of beneficiaries. ${ }^{19}$ In addition, the reform of the WHO's financing structure is blocked by these powerful donor countries. Moreover, donor countries seek to influence the wHo's agenda beyond their formal mandate and voting modalities and financial bottlenecks have meanwhile led to the loss of qualified personal and serious cuts in the wHo budget. ${ }^{20}$

For many years, it has been obvious that the WHO cannot fulfill its mandate under the given circumstances. However, the ongoing global dialogue over finance, which is part of the reform, has not led to a productive change. Even worse-by now a debate on the wHo's role is gaining momentum arguing that the wHO cannot sustain the diversity of its current activities and should therefore select fewer priorities. Rather than providing more funds to meet contemporary global health needs, the wHO is essentially asked to do less (Peoples Health Movement 2013). ${ }^{21}$

\section{5 Trojan Multilateralism}

But how did this situation occur? The relegation of the wHO is part of a trend in global governance politics that documents a general loss of trust in the

18 Ravi Narayan, (PHM), Postal interview with author, 7 July 2014.

19 The Campaign for People's Goals for Sustainable Development (the People's Goals). See more at: http://peoplesgoals.org/about-us/\#sthash.rMsY4iYp.dpuf (accessed 21 February 2015).

20 Devi Sridhar and Lawrence Gostin, "World Health Organization: past, present and future", Public Health 128 (2014), p. 117-118.

21 Peoples Health Movement, wHo Watch Report on Day 2 of the 66th World Health Assembly, 2013. http://www.ghwatch.org/sites/www.ghwatch.org/files/PHM-wHA66_ Day2AReport.pdf (accessed 21 February 2015). 
capacity of UN institutions. In the case of the wHO this loss in trust occurred due to some scandals in the past that highlighted how strongly the pharmaceutical industry was influencing the decisions of the health institution to proclaim a global health emergency. At the same time, a general transformation of the global health field has taken place.

Since it was founded, the WHO's role has changed. Until the 199os the WHO was the leading global health institution. However, by now new actors, financing mechanisms and programs have emerged effecting the marginalization of the wно. The wно has become one actor among many others. In the 21st century the global health field is marked by complex governance architecture, formed by "overlapping and sometimes competing initiatives and programs that involve multiple players addressing different health problems through diverse processes and principles". ${ }^{22}$

Moreover, the wHo, like many other UN institutions, has largely been sidelined by an upcoming Trojan multilateralism. ${ }^{23}$ This multilateralism not only involves various agents, such as private foundations and private initiatives, but also expresses a shift to more discretionary and therefore selective funding. As a result of this changing environment, the wHo faces both financing and governance difficulties and these difficulties weaken the wHo's unique role as a global health institution and authority. ${ }^{24}$

The problem is, moreover, that private health initiatives and agents, such as foundations, have become relevant and influential donors of wHO projects. The emergence of global health initiatives has been a major feature of the wider aid context in the last decade. And this trend documents the contemporary Zeitgeist. Inspired be neoliberal ideology, financiers of health politics, have started favoring market-based reforms and rely on the transnational civil society rather than on international institutions in order to realize programs.

"Global public private partnerships in health (GPPH) emerged in the mid199os, at a time when the UN and its member states became more interested in partnerships. The socio-political shifts in several Western countries, known as "the third way", resulted in the UN viewing the benefits of industry as

22 David P. Fidler, The Challenges of Global Health Governance, Working Paper, 2010, p. 1, published in the context of the CFR's International Institutions and Global Governance program. http://ec.europa.eu/health/eu_world/docs/ev_2011111_rdo1_en.pdf (accessed 15 May 2015). For this diagnosis see also: Ilona Kickbusch, "A Game Change in Global Health: The Best Is Yet to Come", Public Health Reviews 35(2013), p. 1-2.

23 Devi Sridhar and Ngaire Woods, “Trojan Multilateralism: Global Cooperation in Health.” Global Policy 4 (2013), p. 325-35.

24 Ibid. 
"re-legitimizing the UN". Harnessing the private sector for human development, was, and is seen, as a way to enable UN agencies to fulfill their mandates by means of funding and advice from the private sector."25

Especially Gro Harlem Brundtland, who was the wHO's general director from 1998 to 2003, opened the wHO to the private sector. Through these "Private Public Partnerships" wно's functional role changed. The wно became more and more dependent on external agencies.

The Bill and Melinda Gates Foundation, for example, is the second biggest financier of WHO-projects and the world's largest private grant-making foundation. It is a key member of the Global Fund to Fight AIDs, Tuberculosis and Malaria, responsible for financing, governance and advocacy and, due to this financial power, it dominates the international health agenda. ${ }^{26}$ How far this dominance goes is demonstrated by the wHo's decision to give Melinda Gates (of the Bill and Melinda Gates Foundation (BMGF) the keynote speech at the 67th World Health Assembly. The fundamental problem with these private health initiatives is not only that they open gateways to the private sector and have the tendency to detract their agenda from the critical public discourse by favoring a depolitized health approach, but also that they heavily influence the agenda-setting of the wHo. Moreover, the Bill Gates Foundation lacks any form of democratic control, transparency and public accountability and thus one can be suspicious about its agenda, also because the Gates foundation is "tied to projects that the foundation has an interest in funding". 2728 The foundation has strong links with the private sector, such as pharmaceutical corporations and the food industry, leading to permanent conflicts of interest. In some cases, "these corporations directly benefit from foundation grants, and foundations in turn are invested in the corporations to which they award these

25 Van Schaik, Louise G., and Remco van de Pas, "Transnational Governance and Democratic Legitimacy. The Case of Global Health", The Hague Institute for Global Justice \& Clingendae, 2014, http://thehagueinstituteforglobaljustice.org/cp/uploads/ downloadsprojecten/Special_Report_Transnational_Governance_and_Democratic_Legi timacy_July_2014_Chapter_3_1407412573.pdf (accessed 21 February 2015).

26 David McCoy, Interviewed by: Andrew Bowman. "The flip side to Bill Gates' charity billions". New Internationalist, April 1, 2012. http://newint.org/features/2012/04/o1/billgates-charitable-giving-ethics/ (accessed 4 February 2015).

27 Tinashe Njanji, Melinda Gates addresses the World Health Assembly: Civil Society registers its protest, 2014, Peoples Health Movement, http://phm-sa.org/melindagates-addresses-the-world-health-assembly-civil-society-registers-its-protest/ (accessed 20 February 2015).

28 Ibid. 
grants". ${ }^{29}$ One paragon is its focus on "investments in technological products, such as vaccines, instead of social programs and political processes" ${ }^{30}$ At least from the perspective of normative theory of democracy, it seems problematic that a health-agenda lacks any democratic procedures, institutionalized bottom-up strategies, and checks and balances. ${ }^{31}$ Such an agenda is likely to enhance the status of transnational corporations, which follow private and profit-oriented interests and are deeply interwoven into a capitalist mode of production. ${ }^{32}$ And as such, private health initiatives in the form of foundations tend to blur the lines between public and private interest. They upgrade the private sector as a central player in the field and marginalize community health building processes and, even worse, they contradict a coherent health planning in the $\mathrm{WHO}^{33}$

At the same time, a discourse on 'partnerships' between global health initiatives and the wHo has emerged which is suspicious of indirectly restricting the wHO's role to a technical norm-setting agency, whereas the control over the implementation of the health agenda is given to private initiatives and the World Bank. Last but not least, vertical programs, such as the Global Fund to Fight AIDS, Tuberculosis and Malaria, but also Global Alliance for Vaccines and Immunization (GAVI) and Joint United Nations Programme on HIV and Aids (UNAIDS), ${ }^{34}$ create parallel structures weakening the authoritative and coordinative role of the wHO. Thus, on the one hand these changes lead to an inefficient duplication of selected health programs and on the other, they foster a general fragmentation of the global health context. ${ }^{35}$

29 David Stuckler, Sanjay Basu and Martin McKee, "Global Health Philanthropy and Institutional Relationships: How should Conflicts of Interest Be Addressed?” PLoS Med 8 (2011). doi: 10.1371/journal.pmed.100102.

$30 \quad$ Supra note 18; Ibid.; Also see Danny Burns and Clare Gorman, "Designing Inclusive Targets for a Post-2015 Agenda", IDs Policy Briefing 68 (2014), http://opendocs.ids.ac.uk/opendocs/bitstream/handle/123456789/4021/PB68.PDF?sequence=1 (accessed 17 August 2014).

31 Jürgen Habermas, Between Facts and Norms: Contributions to a Discourse Theory of Law and Democracy. London: MIT Press, 1992.

32 Stephen R. Gill, and David Law, "Global Hegemony and the Structural Power of Capital", International Studies Quarterly 33(1989), p. 475-99.

33 Remco Van de Pas and Louise G. van Schaik, "who: Past, Present and Future. Democratizing the World Health Organization", Public Health 128 (2014), p. 195-201.

34 GAVI-Vaccine Alliance is a public-private global health partnership committed to increasing access to immunization in poor countries.

35 Global Health Watch, Civil Society Consultation Paper 2006, http://www.ghwatch .org/sites/www.ghwatch.org/files/HealthSystemsDevelopmentAgenda.pdf (accessed 15 February 2015). 
Moreover, the chronic underfunding of the wHO establishes a kind of selfcensorship at the level of its employees. Before running the risk that health projects are not funded at all, "semi-optimal" deals are made constraining the WHO to single issue-oriented health goals and isolated programs that tend to fragment health systems. This results in disease-specific approaches that delegitimize public funding and resource-management as they express neoliberal top down governance dominated by Global North perspectives. ${ }^{36}$ At the same time, selective and vertical health programs are not capable of installing a set of institutions that would be capable of engaging in long-term planning for sustainable development and planetary stewardship, by including (local, national and transnational) civil society in the context of a bottom-up strategy. ${ }^{37}$ Due to these shortcomings, wide gaps in the access to resources for health remain in many states in the Global South. ${ }^{38}$ Against this background, it is no coincidence that Ebola spread in the three poorest countries in West Africa. This was not a natural but a man-made disaster, not only being caused by wHo's deficient emergency response systems, but also by the dereliction of the international community to support the WHO in its task to strengthen national health systems and capacities of communities. This is another lesson we can learn from the Ebola crisis: In West Africa, the lack of community trust and the financial deprivation of the local and national public health capacities not only delayed reporting and thus the control of the Ebola outbreak, but also expresses the persisting poverty and increasing inequality in access to health.

36 Despite this critique some networks, such as the Third World Network, want to readdress the Millennium Declaration as a core document for the Post 2015 process. At the same time they recognize that the world has changed significantly economically and geopolitically since the 1990s. It is argued that the MDGs did not correspond with the content of the Millennium declaration, which offered an intersectional approach, referring to human rights, to peace-building, security and Good Governance. In this sense the declaration included a more complex understanding of development whereas the MDGs focused one-dimensionally on single goals, thus neglecting the interwoven fields of action. See also: Radhika Balakrishnan and Diane Elson, The Post-2015 Development Framework and the Realization of Women's Rights and Social Justice. New Jersey: Center for Women's Global Leadership, 2012. http://cwgl.rutgers.edu/docman/economic-andsocial-rights-publications/520-post-2015-november-2012/file (accessed 5 May 2014).

37 Kenneth Mwehonge, (HE PS Uganda), Postal and Oral Interview by author on 18 July 2014.

38 Training and Research Support Centre (TARSC), Equity in health in the Post-2015 development goals, EQUINET, ECSA HC TARSC Policy brief 33 (2013), Harare: EQUINET. http:// www.tarsc.org/publications/documents/Pol\%2obrief\%2033\%2opost\%202015.pdf. 
Moreover, what is striking is the insight that a global health agenda, which is based on the myth that the inclusion of the private sector increases the efficiency of health policies, will ultimately fail. Most of the time, global health initiatives are based on philanthrocapitalism, which means combining capitalist enterprise with charity as a new form of health funding. ${ }^{39}$ However, these forms of funding can be characterized as "anti-politics" as they are reducing politics to a technocratic management process and therefore to a misrepresentation of the reality of so-called developing countries. ${ }^{40}$ It is symptomatic for these kinds of initiatives that they have a significant focus on the task of efficiency but not so much on legitimacy, in other words, securing that those who are the addressees of health initiatives are also the authors. ${ }^{41}$ This understanding has the premise that if the outcomes of certain policies are good (in the sense of efficient), then they are legitimate. At first glance this appears reasonable, but it underestimates the risk of paternalism and ignorance of local knowledge production and community abilities which are essential, not only in order to prevent emergencies but especially to improve the social and political determinants of health. In the end, it has to be asked who decides on the base of which criteria if a health initiative and its funding has been successful, efficient and legitimate. Global health initiatives and vertical programs disavow that political capacity building and the empowerment of structurally marginalized regions, groups, and individuals are the most urgent challenges to meet in order to overcome the global health crisis.

Although in these programs allusions to participation, partnerships and community empowerment have become part of the official language they still have the tendency to patronize the structurally marginalized, as they express only a rhetorical shift. With regard to the Gates foundation the critical public health expert Jason Hickel notes:

The strategy goes like this: Talk about the poor as "equals" who share our values; emphasize that development is a partnership; stop casting

39 Gavin Fridell and Martijn Konings, Age of Icons: Exploring Philanthrocapitalism in the Contemporary World, Toronto: University of Toronto Press, 2013.

40 James Ferguson, The Anti-Politics Machine: "Development", Depoliticization and Bureaucratic Power in Lesotho, Cambridge: Cambridge University Press, 1990.

41 On the idea of legitimacy and processes of public legitimation, see: Jürgen Habermas, Between Facts and Norms: Contributions to a Discourse Theory of Law and Democracy, trans. by William Rehg, Cambridge: MIT Press, 1998. 
rich people and celebrities as saviors of the poor; and above all play up the idea of "self-reliance" and independence, with special attention to empowering women and girls. Progressive Westerners love this stuff. This new framing is nothing than a propaganda strategy. ${ }^{42}$

These neoliberal development politics disrespect that health is a common good demanding collective responsibility in form of public institutions on the local, national and international level, which are accountable to societal demands. In this sense, charity-based health projects are likely to become undemocratic and paternalistic. ${ }^{43}$ The same holds true for capitalist enterprises in form of private public partnerships. Both veil conflicts of interest and hegemonic rationalities by prioritizing top down politics in order to maximize profit and influence. This is especially true especially for low and middleincome countries. ${ }^{44}$ Therefore, as long as institutions like the wно depend on the voluntary input of the private sector and private initiatives, instead of being democratically empowered by its member states, any holistic approach enabling a transformation of political processes in favor of equity and human rights is counteracted. ${ }^{45}$ Thus, only a strong participatory attempt, which is not only naming but also actually taking bottom-up strategies seriously, can be qualified to be legitimate. What is needed is a proper funding and democratisation of the wHo's governance procedures.

\section{Wrong Lessons Learned from the Ebola Crisis}

In the aftermath of the Ebola crises, a public debate has emerged arguing that the international community should support the WHO on strengthening national health systems. This is definitely a good step forward. But the problem lies in the way this debate is framed. Right now the complete focus lies on public-health emergencies and on the need to reform the wHO to enhance the

42 Jason Hickel, The death of international development. Red Pepper, February 2015. http://www.redpepper.org.uk/essay-the-death-of-international-development (accessed 12 March 2015).

43 Supra note 39 .

44 David McCoy, Kembhavi Gayatri, Jinesh Patel and Akish Luintel, "Health Policy: The Bill \& Melinda Gates Foundation's grant-making programme for global health", The Lancet 373 (2009), p. 1645-53.

45 Supra note 14. 
agency's rapid response capacity. ${ }^{46}$ Recently, several concepts have been discussed based on a concept of global health security, stressing the importance of resilient health systems in responding to outbreaks of diseases and other health emergencies. These concepts are: A Global Outbreak Alert and Response Network, based on the WHO and groups including the Red Cross, U.s. Centers for Disease Control and Prevention, and Doctors Without Borders. Moreover, a Global Health Emergency Workforce is has already been discussed. And last but not least, there is a World Bank plan to build large specialized treatment centers and to extend care to local communities on the base of a global fund that would issue bonds to finance important measures that fight pandemics, such as training healthcare workers in advance. ${ }^{47}$ There are four reasons why one should be skeptical about these concepts: My argument is that these concepts are likely to fail because they reproduce the pathological patterns of the given aid practice and produce new ones.

First, strengthening national health systems is a good idea but it should go beyond disaster preparedness. This is because the concept of disaster preparedness has a tendency to focus on policies that only handle an acute crisis in form of short-sighted and single-issue oriented initiatives instead of working on conditions to overcome those structures, which permanently produce crises. To go beyond disaster preparedness means to reject the problematic acceptance that crises are unavoidable, or rather natural and not man-made. The point is that the current crisis management underscores the importance of strengthening primary health care and public health systems.

Second, another fashionable approach in response to the Ebola crises is to improve the resilience of health systems. In psychology resilience is defined as an individual's ability to properly adapt to stress and adversity. And as such, the paradigm of resilience should make us wonder whether this is actually more than just the typical concept of the neoliberal Zeitgeist, focusing on false ideas of individual self-empowerment and self-entrepreneurship. The message is that individuals should develop capacities in order to be able to cope with desperate living conditions thereby negating the collective responsibility of the international community to improve these conditions. The concept of

46 Sarah Roache, Lawrence O. Gostin, Dan Hougendobler and Eric Friedman, Lessons from the West African Ebola Epidemic: Towards a Legacy of Strong Health System, O'Neill Institute, Briefing Paper No. 10 (2014). http://www.law.georgetown.edu/oneillinstitute/ resources/documents/Briefing1oEbola2inTemplate.pdf (accessed 12 March 2015).

The involvement of the private sector is a key element in this strategy. However, this strategy might again be built on the acceptance of the myth that capital markets can force governments and NGOs to be more effective in pandemic preparedness. 
disaster preparedness disguises that structural misery becomes privatized and individualized.

Third, it is highly problematic to embed the global health agenda and its funding in a security narrative. Treating health like a security threat disregards that health is first of all a human right. One example is the discussion on the white helmets in response to the Ebola crisis. The "white helmet initiative" is a six-point plan promoted by the German government in order to manage international health emergencies. Medical experts should be ready to be deployed in conflict areas within only a few days. However, such an initiative focuses merely on acute crises and rests on the logic of external humanitarian interventions based on expertise from outside instead of strengthening local and national health capacities in the long run. Moreover, it bears the risk that human beings are no longer perceived as bearers of rights but as risk objects. It leads to 'bio politics', ${ }^{48}$ a power constellation where humans are deprived of their rights as they are reduced to 'bare life', regulated by diffuse networks of non- and quasi-governmental and foreign agencies isolated from political accountability ${ }^{49}$ In the worst case, such a paradigm could be used to justify authoritarian interventions and the politics of an emergency state. And this could lead to a situation where, in the name of Global Health, billions of Euros are poured into a national security apparatus instead of the health systems. ${ }^{50}$ This is a lesson we can learn from the recent Ebola crisis where there was, at some point, a trend to reframe health actions as an authoritarian population control through military and police.

Fourth, the response to Ebola also reproduces an old reflex: when a health emergency appears, new institutions are created instead of strengthening the wHo's constitutional mandate and capacity to act by proper funding. Thus, the World Bank Group-plan to establish a Pandemic Emergency Facility (PEF) - a proposal for financing actions to handle pandemics in developing countries-is symptomatic. These initiatives and programs follow the same logic as vertical programs, such as UNAIDS or GAVI,- - they contribute to the further fragmentation of the global health field.

48 Michel Foucault, "The Birth of Biopolitics", in Paul Rabinow (ed.): Ethics: Subjectivity and Truth, New York: The New Press, 1997, p. 73-79.

49 Giorgio Agamben, Homo Sacer: Sovereign Power and Bare Life. Stanford: Stanford University Press, 1998, p. 8.

5o Stefan Elbe, Security and Global Health: Toward the Medicalization of Insecurity. Cambridge: Polity Press, 2010. Also see Peter Streefland, Problems and potential in International Health: Transdisciplinary Perspectives. Amsterdam: Het Spinhuis, 1998, p. $35^{-50}$. 
The Right Lessons to be Learned: The wHо has to be Reformed on the Base of Global Constitutionalism and on Democratic Principles

To learn from the Ebola crisis means to acknowledge that any health approach, which is only tackling emergencies, is inappropriate for overcoming health inequalities in the longer term. It implies recognizing that the WHO, at its present stage, is barely capable of functioning as a global agency that is working in the public interest and in favor of the people's needs and interests. What is needed is a strong commitment of the international community to re-build the WHO as a global health authority on the base of a human rights account, an account, inspired by Kantian principles of universal rights, relying on the assumption of moral dignity and equality of all human beings as individuals and legal subjects, regardless of their nationality. ${ }^{51}$ Such a claim is far from being utopian. It fact, it has always inspired the UN system. Let me start from a very broad and general observation: Processes of globalization have challenged territorial premises of sovereignty and particularistic presumptions about rights that are based on a strong sense of national belonging. Most human rights lawyers point out that the emergence of international human rights law post-World War II represents one of the most profound challenges to the notion that state sovereignty is irreducible and impermeable.52 Several legal scholars note that the nature of international law has changed insofar as we see an emerging "global constitutionalism" grounded in supra-national norms and institutions that fulfill functions hitherto fulfilled by national constitutions and states. ${ }^{53}$ In debates about global constitutionalism it is argued that there is a general shift in international law. While in a classical view international law was understood as a system of state cooperation, based on self-interest and state-autonomy, it us now becoming increasingly common to interpret it as a global legal order that transcends state boundaries and, even more, addresses responsibilities based on human rights

${ }^{1}$ Immanuel Kant, Schriften zur Anthropologie, Geschichtsphilosophie, Politik und Pädagogik 1. Werksausgabe XI (ed. By W. Weischedel,). Frankfurt a. M.: Suhrkamp Verlag. 1996, p. 150, and also, Immanuel Kant, Die Metaphysik der Sitten, Werkausgabe VIII (ed. by W. Weischedel), Frankfurt a. M.: Suhrkamp Verlag, 1996, p. 430.

52 Harold Hongju Koh, "Complementarity between International Organisations and human rights: The rise of transnational networks and the third globalization." Human Rights Law Journal 21 (2000), p. 307-11.

53 Jürgen Habermas, "The Constitutionalization of International Law and the Legitimation Problems of a Constitution for World Society." Constellations 15 (2008), p. 444-55. 
that go beyond the state. ${ }^{4}$ Modern developments of international justice as well as injustice are embedded in a longstanding debate between legal ${ }^{55}$ and moral cosmopolitanism ${ }^{56}$ and their skeptical counterparts, sovereignty and state centered views. ${ }^{57}$ The 'family' of contemporary cosmopolitanists draw upon ideas of world citizenship and inclusion, of more or less Kantian principles of universal rights. ${ }^{58}$ In reference to Kant's philosophy of law and the state it can be concluded that global constitutionalism should be understood as global democratic rule of law ${ }^{59}$ (i.e., democratic not liberal constitutional${ }^{i s m}{ }^{60}$ ), highlighting that the normative punch line of modern law is to overcome arbitrariness through a universalized conflict solution based on the congruence between authors and addresses of law. ${ }^{61}$

At the diagnostic level scholars who identify with the concept of democratic constitutionalism share the intuition that globalization goes beyond mere functional interdependencies and coordinative schemes established and

54 Christian Tomuschat, "Obligations arising for State with or without their will", Hague: Recueil des cours (1993), p. 241.

55 Hans Kelsen, 'Das Problem der Souveränität und die Theorie des Völkerrechts'. Tübingen: 1928; Hans Kelsen, 'Reine Rechtslehre', Vienna: 1992.

56 F. Radbruch, 'Rechtsphilosophie', in S. Paulson and R. Dreier (eds.) 'Studienausgabe', Heidelberg, 2003.

57 Prosper Weil, Towards relative Normativity in International Law? 3 American Journal of International Law 77 (1983), p. 413-442; Carl Schmitt, Der Begriff des Politischen. Berlin, 1987 .

$58 \quad$ Supra note 51.

59 Ibid., Kant 1996a: p. 48, 127ff., 161, 224; Kant 1996b: p. 43off., 434.

6o For a distinction between liberal and democratic constitutionalism see Jürgen Habermas,. Konstitutionalisierung des Völkerrechts die Legitimationsprobleme einer verfassten Weltgesellschaft. In: Brugger, Winfried/Neumann, Ulfried (eds.): Rechtsphilosophie im 21. Jahrhundert, Frankfurt, 2008, p. 360-379.

61 Jürgen Habermas, Hat die Konstitutionalisierung des Völkerrechts noch eine Chance?. In: Jürgen Habermas, Der gespaltene Westen, Frankfurt a. M., 2004, p. 113-193; Jürgen Habermas, Eine politische Verfassung für die Weltgesellschaft. In Habermas, Jürgen. Zwischen Naturalismus und Religion Philosophische Aufsätze. Frankfurt, a. M., 2005, p. 324-365; Klaus Günther, Menschenrechte unter Bedingungen fragmentierter Staatlichkeit—Vom vertikalen zum horizontalen Verständnis der Menschenrechte. in: Deitelhoff, Nicole/Steffek, Jens (eds.): Staatlichkeit ohne Staat? Chancen und Grenzen von Recht und Verfassung jenseits des Nationalstaats, Frankfurt, 2009, p. 259-281; Rainer Forst, Das Recht auf Rechtfertigung, Elemente einer konstruktivistischen Theorie der Gerechtigkeit, Frankfurt a. M. 2007; Jost.Delbrück, Prospects for a World (Internal) Law? Legal Developments in a Changing International System, 9 Indiana Journal of Global Legal Studies 401 (2002), p. 401-431. 
maintained by self-contained nation-states, and that globalization is about cooperative problem-solving concerned with general humanity and acknowledging individuals as agents of justice. ${ }^{62} 63$ In programmatic terms they envision a global order able to establish universally justified and applicable principles and norms. ${ }^{64}$ These perceptions run counter to statist views of the international order insofar as they deny the strict notion of nation-states as the ultimate source of legal and moral authority, and the strict notion of nationstates' integrity that is guaranteed by the principles of non-intervention and national self-determination and sovereignty. ${ }^{65}$

Apart from that, the emergence of cosmopolitan norms has been accompanied by debates about refugee, immigrant and asylum status. ${ }^{66}$ Accordingly, transformations of citizenship-concepts lead to a decoupling of rights and identity — not least by invoking human rights conventions and demanding the recognition of rights for particular vulnerable, discriminated or minority groups. ${ }^{67}$ These decouplings of rights and national belonging challenged the claim that nation-states are the ultimate source of normative authority. Looking at the central 'universal' legal code, the Universal Declaration of Human Rights (UDHR), we are by now at a point that, starting from the drafting debates in the mid 1940 os up to present developments, there are—broadly speaking — broadly speaking - two accepted types of human rights norms identified in international treaties and conventions, i.e. civic-political and socio-economic rights. Civic-political rights include norms regarding physical and civil security on the

62 Ibid.

63 See also: C. Joerges, 'Deliberative Supranationalism, A Defence'. European Integration Online Papers, 2001, available at eop.or.at/eiop/texte/2001-008.htm (accessed on 15 February 2015).

64 O. Gerstenberg, "Expanding the Constitution Beyond the Court: The Case of EuroConstitutionalism" 1 European Law Journal 8 (2002), p. 172-192.

65 J. Kokott, "Der Schutz der Menschenrechte im Völkerrecht", in Lutz-Bachmann (ed.): Recht auf Menschenrechte. Menschenrechten, Demokratie und internationale Politik, M. et al., Frankfurt a. M., 1999, p. 178-198; Martti Koskenniemi, The gentle civilizer of Nations: The rise and fall of international law 1870-1960. Cambridge: Cambridge University Press, 2001; and R. McCorquodale and P. Simons, 'Responsibility beyond borders: state responsibility for extraterritorial violations by corporations of international human rights law'. 4 The Modern Law Review 70 (2007), p. 598-625.

66 Seyla Benhabib, 'Twilight of sovereignty or the emergence of cosmopolitan norms? Rethinking citizenship in volatile times'. 1 Citizenship Studies 11 (2007), p. 19-36.

67 Yasemin N. Soysal, 'Limits of citizenship: Migrants and postnational membership in Europe', Chicago: University of Chicago Press, 1994; G. Delanty, 'Citizenship in a Global Age: Society, culture, politics', Buckingham: Open University Press, 2000. 
one hand-like prohibition of torture, slavery, inhumane punishment, arbitrary arrest, guarantees of legal personhood and equality before the law-and (although they are at the level of concrete application much more contested) norms regarding civil and political empowerment on the other hand-like freedom of thought, assembly, voluntary association, guarantees of political participation. Socio-economic rights include norms regarding the provision of goods meeting basic personal and social needs (nutrition, shelter, health care, education) as well as norms regarding goods meeting basic economic needs (work, fair wages, decent living standard, social security). The decisive point is that both groups of rights imply potential claims of individual persons against their respective states. Apart from these 'first-generation rights' there is another class of human rights - however less settled and more contestedacknowledged in international agreements, i.e. collective rights of peoples or groups held against their respective states, either in form of collective rights of self-determination of people regarding their political status and economic, social and cultural development or in form of protective rights for ethnic and religious minorities to the enjoyment of their cultures.

Beyond that, some legal experts point out that the United Nations Charter functions as a provisional constitution of the International Community. ${ }^{68}$ They note that the UDHR relies on a universal principle of mutual recognition and cooperation which is placing duties on states, international institutions and non-governmental organizations such as non-profit Civil Society Oganizations or Business-Entrepreneurs (in short all agents who are involved in global governance) with respect to human rights. ${ }^{69}$

However, legalisation as well as juridification of international and transnational relations are in phenomenological, in systematic and normative terms rather ambiguous, the binding and implementing force of principles, rules and normative standards is contested; the status of norms and the subjects of the law are indistinct; processes and practices of jurisgeneration are highly inconsistent; legacies are fragmented according to standards and fields of jurisdictions. Such diverse normative spheres like lex humana, lex mercatoria,

68 Bardo Fassbender, The United Nations Charter as the Constitution of the International Community. Leiden: Brill, 2009.

69 Ernst-Ulrich Petersmann, “Time for a United Nations 'Global Compact' for Integrating human rights into the law of Worldwide Organizations. Lessons from European Integration", European Journal of International Law 13 (2002), p. 621-50. See also Nadja Meisterhans, Menschenrechte als weltgesellschaftliche Herrschaftspraxis. Zur Konstitutionalisierung und Demokratisierung des Weltrechts. Baden-Baden: Nomos Verlag, 2010. 
lex elextronica etc. are not evolving simultaneously and within an overarching "order". ${ }^{70}$ Two phenomena are particularly striking insofar as they reveal inconsistencies in systematic and normative terms. On the one hand, it seems that we are confronted with simultaneous processes of legalisation and delegalisation. ${ }^{71}$ The upgrading of law, esp. fundamental norms, and the rise of discretionary power of interpreting these norms can be described as dialectic. More precisely: references to (global or universal) fundamental norms seem to be consented at a very general and abstract level, at the same time they are substantiated and applied in hegemonic and idiosyncratic terms. On the other hand, juridification qua judicialisation, by tribunal-driven conflictresolution, is highly fragmented at the institutional level and rule-bound in a negative sense. That is to say, contesting and competing jurisprudence can only rely on partial agreement and not on procedural remedies. Trans- and international rule-making, rule-implementation and rule-application produce partial legacies which potentially induce "counter-legacies" (through public scandalizations by critical civil society actors and social movements, opposing jurisprudence at different levels, and recourse to alternative bodies of conflictresolution). So, in systematic terms, legalisation has to be specified in order to explain its normative potentials and to identify counter-productive and pathological side-effects.

The cosmopolitanisation of jurisdiction or judicial globalisation is itself a complex field of different practices and institutional structures, relating to the spread in transnational, esp. regional human rights courts, ${ }^{72}$ international human rights agencies ${ }^{73}$ on the one hand and to the broadening of the

70 Martti Koskenniemi, International Law: Between Fragmentation and Constitutionalism, 2008, http://cigj.anu.edu.au/cigj/link_documents/KoskenniemiPaper.pdf (accessed 10 April 2014); Anne Marie Slaughter: Disaggregated Sovereignty: Towards the Public Accountability of Global Government Networks, 2 Government and Opposition 39 (2004), p. 159-19o; Gunther Teubner, The Anonymous Matrix: Human Rights Violations by "Private” Transnational Actors, The Modern Law Review 69 (2006), p. 327-346.

71 Ibid., Koskenniemi.

72 Such as the European Court of Human Rights (at European level, the European Court of Justice, the CoE General of Human Rights (DGII) and the European Committee for the Prevention of Torture are of relevance in the context of human-rights jurisdiction), the Inter-American court of Human Rights (as well as the Inter-American Commission on Human Rights and the Inter-American Commission on Women), and the African Court on Human and Peoples' Rights.

73 An overview of Human Rights Bodies of the UN is available at http://www.ohchr.org/ english/bodies. 
institutional application of universal jurisdiction. ${ }^{74}$ Part of what is often referred to as phenomena of 'judicial globalisation' is not only the spread of trans- and international judicial bodies of various kind (tribunals, arbitration bodies, courts), material scope (human rights law, trade and economic law, environmental law etc.) and area of jurisdiction (transnational for example European, Asian, pan-American or global), but also a spread of interpretative schemes transcending national-statist jurisprudence. That is to say, national judiciaries consider trans- and international legal sources as well as comparative methods considering the decisions and the jurisprudence of foreign (esp. constitutional) and transnational courts. ${ }^{75}$ Part of this trend is a growing international network-structure between judges and court-members as well as coordinating practices of different national jurisdictions in international litigation. ${ }^{76}$ These practices of judicial borrowing of legal sources beyond their respective national system is not just resulting from functional imperatives and interdependence structures but to a certain extent the result of 'global mirror' justifications holding that where global consensus exists in form of customary international law or jus cogens (obligatory law), international and comparative legal materials presumptively reflect commitments that are held 'domestically' as well as internationally, especially with regard to fundamental rights. ${ }^{77}$ So, unsurprisingly, national courts frequently cite in constitutional and human rights issues the human rights jurisprudence of such transnational tribunals as the European Court of Justice and its Inter-American Counterpart. ${ }^{78}$

74 Flaherty shows that such diverse leading national (or regional) courts like in India, Canada, Zimbabwe, Hong Kong, South Korea, Botswana, Israel, and Germany cut across lines. The South African constitution even requires reference to international and comparative law for domestic interpretation. In his study of the us-Supreme Court jurisprudence, Flaherty points out that even us courts - after an isolationist phase - consider international and foreign sources, most notably in decisions on privacy, affirmative action, and the death penalty. At the same time, he highlights the mainstream doctrine of the Founding generation, esp. its Federalist leadership that was holding "the law of nations in sufficient regard as to create a presumption that the Constitution should be interpreted consistent with international law where possible" M. S. Flaherty, 'Judicial globalization in the service of self-governance'. 4 Ethics and International Affairs 20 (2006), p. 480.

See also S. H. Cleveland, 'Our international constitution', 1 Yale Journal of International Law 31(2005), 1-125.

75 Supra note 70, Slaughter; ibid., Flaherty.

76 For an overview, see supra note 65 , Kokott.

77 Supra note 74, Flaherty.

78 Ibid. p. 503 . 
Regarded from this point of view it is far from being arbitrary to refer to a universal code of recognition as a point of normative and systematic orientation in international law as these citations can only work by hypo stating a regulative vision of universal law. ${ }^{79}$ At the same time they are, so the assumption, directed at an amelioration of the factual existing international legal order-be it in normative and dogmatic terms, in practical and institutional, or in procedural terms. Challenging the existing order and establishing critical movements or counter-legacies is not directed at denying the idea of universal law but at improving and restructuring it in to order to make it more responsive to individual demands of justice and to participatory inclusion of agents of justice.

In other words: Although the development of a plurality of legal regimes seems to be antithetical to universal and monist interpretations of law, we can identify a law's inherent normativity and function and that is to guarantee equal treatment and normative coherence. ${ }^{80}$ In this respect, fragmentation is factually challenging transparency, responsibility and representativeness of a legal system, but it cannot escape the universal inclusive legal grammar (the internal legal perspective). So, despite fragmentation and decentralisation, references to an abstract legal code are ineluctable. The internal legal logic is accordingly not to produce fragmented, exclusive rationalities alien to universality, but to organise diversity by a universal meta-code. Transnational jurisgeneration in nuce already relies on an ethos of international law. This reliance is not arbitrary insofar as any kind of legality is constitutively structured by an inherent logic that strives for (principled) unity and coherence-despite factual differentiation and fragmentation. In this light, we can put on view that the present multi-level and multi-institutional arrangements of global law are not antithetical to the idea of a universal legal framework but an intermediary step towards a legal order 'unified' by an abstract rule of recognition. ${ }^{81}$ In the line of Kelsen's reading of law's internal logic (as developed in his book about a 'Pure Theory of Law', ${ }^{82}$ I assume that there is a necessary relation between

79 K. Günther, 'Rechtspluralismus und universaler Code der Legalität als rechtstheoretisches Problem'. in: K. Günther and L. Wingert (eds.) 'Die Öffentlichkeit der Vernunft und die Vernunft der Öffentlichkeit. Festschrift für Jürgen Habermas', Frankfurt a. M., 2001, p. 434-45.

8 o Ibid., p. 541 .

81 Following monist and constitutionalist approaches of international law—cf. paradigmatically Kelsen 1992 for the idea of a 'Stufenfolge des Rechts', supra note 55, Hans Kelsen, 1992.

82 Hans Kelsen, Mit einem Anhang: Das Problem der Gerechtigkeit, Mohr Siebeck, 2014. 
legal 'meanings', i.e. legal norms (however fragmented they be) cannot evolve independently, but are embedded in a system of interrelated, derivative and coherence-driven processes of interpretation. The point is: if one chooses the language of law, one cannot withdraw from its inherent normativity anymore. The result is that global law, too, despite the existence of different legal stages, contexts and functional regimes, follows a monistic alignment. So, the present multi-level-arrangements of global law are neither adversary to a universal legal framework nor detached from a 'Stufenfolge' of law. The idea is that legal meaning can only be generated by reference.

What does this mean for the reform of the WHo? If we take the Preamble of the UDHR seriously-it outlines that national and international human rights law rests on the 'recognition of the inherent dignity and of the equal and inalienable human rights of all members of the human family' - and if we consider that human rights have become part of the general principles of law and are recognized by civilized nations (Art. 38 of the Statute of the International Court of Justice), it seems reasonable to understand the wHo's role as that of an organization, which has specific responsibilities based on human rights that are institutionalized on a global scale. It is arguable that the WHO's constitution is not only inspired by United Nations Charter and UDHR but, beyond that, it has a constitutional mandate in the context of an emerging global rule of law. And if we are willing to understand the WHo's constitutional mandate embedded in a universal ethos of international law we could further conclude that states have a legal obligation to support this institution to fulfill its mandate. Such legal obligation even goes "[b]eyond [the] ratification of human rights treaties" [as the] "the UN Charter obliges all UN members "to take joint and separate action in co-operation with the Organization for the achievement of... [the] purposes" of the UN, including to "promote universal respect for, and observance of, human rights and fundamental freedoms for all." ${ }^{3}$ This normative idea has not only inspired the Universal Declaration of Human Rights, but also the Vienna Declaration and Program of Action where a duty of all states is outlined "to promote and protect all human rights and fundamental freedoms." ${ }^{84}$ Additionally, this obligation is not only backed up

83 With reference to the United Nations Charter: Lawrence O. Gostin, Gorik Ooms, Mark Heywood, Just Haffeld, Sigrun Møgedal, John-Arne Røttingen, Eric A. Friedman, and Harald Siem: The Joint Action and Learning Initiative on National and Global Responsibilities for Health World Health Report (2010) Background Paper, No 53, p. 13f., http://www.who.int/healthsystems/topics/financing/healthreport/53JALI.pdf (accessed 10 April 2014).

84 Ibid. 
through the General Comment 14 of the UN Committee on Economic, Social and Cultural Rights but also by reports by the UN Special Rapporteurs on the right to health. ${ }^{85}$ These reports have been complemented by decisions of several national courts. ${ }^{86}$ Also from relevance is that "the ICESCR itself requires states to take steps, individually and through international assistance and cooperation, especially economic and technical, to the maximum of [their] available resources, with a view to achieving progressively the full realization of the" right to health and other human rights." 87 And last not least it also should be mentioned that the Commission on Economic, Social and Cultural Rights has emphasized an international duty to assist states who are not capable of providing an infrastructure to ensure the realization of human rights. The argument is that "in accordance with Articles 55 and 56 of the Charter of the United Nations, with well-established principles of international law, and with the provisions of the Covenant itself, international cooperation for development and thus for the realization of economic, social and cultural rights is an obligation of all States. It is particularly incumbent upon those States which are in a position to assist others in this regard. General Comment 14 states that "it is particularly incumbent on States parties and other actors in a position to assist, to provide this assistance to "enable developing countries to fulfill their core and other" comparable obligations. ${ }^{88}$

In this sense, it is necessary to rethink the global health agenda as an essential element of international obligations. Thus, it is demanded, for example, in the Final Report of the Commission on Social Determinants of Health in the WHO. ${ }^{89}$

Coming back to our discussion about financing global governance for health, this would imply that there are human rights-based arguments, which call states to set up institutions and procedures that ensure the implementation of human rights. In this context, the question would be to how to establish compensatory financing mechanisms which are capable of overcoming the structural inequality of the access to health. But to do this, an integrated health

\footnotetext{
85 Ibid. p. 14 .

86 Ibid.

87 Ibid.

88 Ibid. p. 15. With reference to the Committee on Economic, Social and Cultural Rights, General Comment No. 14: The right to the highest attainable standard of health. New York, United Nations, 2000 (U.N. Economic and Social Council E/C.12/2000/4, http://www .unhchr.ch/tbs/doc.nsf/\%28symbol\%29/E.C.12.2000.4.En (accessed 10 April 2014).

89 World Health Organization, Closing the Gap in a Generation: Health Equity through Action on Social Determinants, Final Report of the Commission on Social Determinants on Health. Geneva: wHo Press, 2008.
} 
approach is required that is centered in a comprehensive understanding of human development and on human rights. This involves questioning specific health goals and isolated programs that tend to fragment health systems. The international community needs to establish a robust financing mechanism that ensures a fair share of burdens between the rich and the poor. And in this sense, we need a reform of the wHo. However, such a reform should be oriented towards a democratic and publically organized model for financing global governance for health, capable of recognizing the structural e.g. political and social determinants of health by providing institutional mechanisms that lead to the equalization of social protection.

\section{Reforming wHo Through Involvement of Critical Civil Society}

In the last section I have argued that at least from a normative perspective-i.e. on the base of concepts on global constitutionalism - states do have responsibilities based on human rights to support international institutions that realize the human rights agenda. So far I have concluded that reforming the wHo will rely on the transformation of global governance financing health. But such a reform - and this is my last thesis-will also depend on the capacity of local, national and transnational critical civil societies motivated by non-profit interests and social movements to push governments and the international community to be sensitive to the complex conditions of health and wellbeing. If the goal is to establish a form of global governance that allows the people affected to participate in policy-making, political structures must be created at the national and supranational level that suit a human-rights based bottomup logic oriented towards democratic self-empowerment. Therefore, a reform of the wHо in the interest of the people will reckon on critical voices having a base in these civil society contexts.

In the last decades local and transnational health organizers and human rights activists have been often successful to use human right talk (the human right to health) as a reference for both legal and democratic selfempowerment. Nevertheless, we have to be aware of the ambivalence inherent in human rights discourse; it can be hegemonically and ideologically abused.

It should be recalled that - at the UN level in particular - the current model of global governance has been organized as a multi-stakeholder process since the 1990s. Procedures explicitly incorporate non-state actors. It is of particular relevance that civil society has been upgraded. But this trend is not without ambivalence as it results from the fact that financiers of health politics (inspired by neoliberal ideology) favor market-based reforms and look to civil society rather than states to realize programs. Since their rise to prominence in 
the last decades, health-related NGOs for example have grown exponentially in size and stature. Frequently, NGOs carry out development measures that should be performed by the state. In the context of the new raison d'etat states are increasingly, giving up leadership roles, thus systematically delegating the provision of public services to non-state actors. ${ }^{90}$

NGOs are still considered as the "good guys", especially by the public. However, this view ignores the fact that NGOs compete with each other for funding from governments and private-sector corporations. NGOs do not operate outside of general system constraints; rather, they face a certain pressure to professionalize and they are at risk of becoming dependent on donors. ${ }^{91} \mathrm{NGOS}$ therefore are at risk of being coopted by national governments, international organizations but also by large philanthropic foundations financed by the private sector. ${ }^{92}$ By involving civil-society players, governments are increasingly able to legitimize undemocratic decisions. When NGOs mitigate crises, theyoften unintentionally—help to stabilize unjust power structures. ${ }^{93}$ "The other issue is that there is often a gap between the analysis and description of the problems and the solutions that are being put forward. The solutions tend to be those that are always praised in ways that will be acceptable to all parties and the powerful interest groups." ${ }^{44}$ Taking this into account it implies that the WHO must find a way to realize the full potential of those NGOs who have strong links with social movements.

In other words, in order to organize a democratic reform of the wHO and global governance for financing health it is crucial to strengthen the collaboration between the WHO and those NGOs rooted in social movements and communities. Such partnerships already exist in the context of the wHo's Civil Society Initiative (CSI) and concrete proposals have been made in the context of the wH O's Health for All strategy. ${ }^{95}$ But what we can learn from the discussion on philanthrocapitalism and the deficits of an aid-centered paradigm is

9o Aziz Choudry and Dip Kapoor (eds), NGOization. Complicity, Contradictions and Prospects, London, 2013.

91 Nicoletta Dentico, Nutrition, Pathologis of Power and the Need for Health Democracy, 2 Development 57 (2014), p. 184-191.

$92 \quad$ Supra note 14.

93 David McCoy, Medact/Phm Oral Interview, 3 July 2014; K. M. Gopakumar, Third World Network, Oral and Postal Interview, 6 August 2014; David Sanders, PнM, Oral Interview, 27 July 2014.

94 David McCoy, Medact/PHм Oral Interview, 3 July 2014.

95 World Health Organization, "A new global health policy for the twenty-first century: an NGO perspective." Outcome of a formal consultation with nongovernmental organizations at WHO in Geneva at 2 and 3 May 1997. http://whqlibdoc.who.int/hq/1997/WHO_ PPE_PAC_97.3.pdf (accessed 3 May 2015). 
that a clear distinction has to be made between those NGOs which have strong links with the corporate sector and those who represent non-profit and public interests. What is needed is a formal representation of critical NGOS on the Executive Board and the World Health Assembly and also in the regional offices, based on a constitutional mandate. ${ }^{96}$ Such a formal presentation should involve a consultative status for NGOS, including speech and voting rights built on and qualified by their capacity to represent structurally marginalized and vulnerable groups such as women, disabled and indigenous people etc.

This proposal is inspired by (Neo)Kantian models of deliberative democracy which share the claim that political-agenda-setting and decision-making should result from fair and reasonable discussions provided by procedures that at least in an ideal perspective ensure the congruence of authors and addressees of law. ${ }^{97}$

In a non-ideal perspective this would at least imply paying greater attention to marginalized groups who have been traditionally excluded from the political agenda-setting and policy-making.

Against this background, it is reasonable to involve local and transnational NGOs and social movements qualified by their capacity to represent structurally marginalized and vulnerable groups in the wHO's consultant and monitoring mechanisms and, more important, in the wHO's policy formulation and strategy development. However, the least thing that should be kept in mind is: Taking into account that the NGO community is diverse and that northern NGOs, due to financial recourses, are in a privileged position to influence policy-making at the state and global level, and being aware that NGOs risk to be instrumentalized and coopted by both national governments and the

$96 \quad$ Supra note 33, p. 195-201. For a detailed proposal to upgrade the World Health Assembly see also Ilona Kickbusch, Wolfgang Hein and Gaudenz Silberschmidt, 'Addressing Global Health Governance Challenges through a New Mechanism: The Proposal for a Committee C of the World Health Assembly' The Journal of Law, Medicine \& Ethics 38 (2010), p. 560.

97 Rainer Forst, Kontexte der Gerechtigkeit. Politische Philosophie jenseits des Kommunitarismus und Liberalismus, Frankfurt a. M, 1994; Jürgen Habermas, Faktizität und Geltung. Beiträge zur Diskurstheorie des Rechts und des demokratischen Rechtsstaats. Frankfurt a. M: 1998; Jürgen Habermas, Die postnationale Konstellation und die Zukunft der Demokratie. In: Habermas, Jürgen. Die postnationale Konstellation, Politische Essays. Frankfurt a. M., 1998, p. 65-90; Jean L. Cohen, Rethinking Human Rights, Democracy, and Sovereignty in the Age of Globalization, 4 Political Theory 36 (2008), p. 578-6o6; and Hauke Brunkhorst, Die Globale Rechtsrevolution. Von der Evolution der Verfassungsrevolution zur Revolution der Verfassungsevolution?. in Ralph Christensen/ Bodo Pieroth (eds): Rechtstheorie in rechtspraktischer Absicht, Fs Müller, Berlin: Dunker \& Humblot, 2008, p. 9-34. 
private sector, the WHO should find a strategy to finance those civil society actors who have strong links in communities and social movements and especially those coming from the South. Here, the Peoples Health Movement (PHM) is a good example. It functions as a transnational network that brings together grassroots health activists, health workers, critical civil society organizations, and academic institutions, that are particularly hosted in low and middle-income countries. PHM not only pushes for various campaigns associated with the right to health and health for all but also monitors the work of wно, by attending the World Health Assembly and the Executive Board, thus producing critical comments on WHO resolutions. The PHM also publishes the "Global Health Watch", a report that stimulates an alternative discourse on global health issues and healthcare. In a first step, the wHO could decide to integrate initiatives like the PHM in a more formalized and systematic way into its bodies by financing their projects and by organizing public hearings during the World Health Assembly where critical health activists can meet and challenge the given health agenda. The point is that institutions can only learn through critique from those who are addressees of their policies. To cut the chase: The challenge to be met is to organize permanent institutional learning-processes through the systemic involvement of critical civil society, thus challenging the given hegemonies of neoliberal thinking, which are also prevalent among some parts of the (established) NGO-community. The wHO could regain legitimacy if it was using this kind of expertise more properly. If we are willing to accept that the existing aid mechanisms and neoliberal politics are inadequate to overcome poverty and poverty-related health problems, especially but not only in low-income countries, we should seriously think about global institutions and processes capable of redistributing wealth. Recently, the German Chancellor Angela Merkel gave the keynote-speech in the opening of the 2015 World Health Assembly in Geneva. Merkel stressed the need to reform and rebuild the WHO as global health authority. Now it is up to the critical NGO community to push governments to realize their promises to strengthen the wHO. 